\title{
PHASE EQUILIBRIA FOR $\mathrm{CO}_{2}-\mathrm{C}_{2} \mathrm{H}_{5} \mathrm{OH}-\mathrm{H}_{2} \mathrm{O}$ SYSTEM
}

\author{
SHIGEKI TAKISHIMA, KOZO SAIKI, KUNIO ARAI \\ AND SHOZABURO SAITO \\ Department of Chemical Engineering, Tohoku University, Sendai 980
}

\begin{abstract}
Key Words: Phase Equilibrium, Supercritical Fluid Extraction, Equation of State, Local Molecular Distribution, Carbon Dioxide, Ethanol, Water

The phase equilibria in the binary systems $\mathrm{CO}_{2}-\mathrm{C}_{2} \mathrm{H}_{5} \mathrm{OH}, \mathrm{CO}_{2}-\mathrm{H}_{2} \mathrm{O}$ and in the ternary system $\mathrm{CO}_{2}-\mathrm{C}_{2} \mathrm{H}_{5} \mathrm{OH}-\mathrm{H}_{2} \mathrm{O}$ were measured at temperatures near the critical point of $\mathrm{CO}_{2}$.

The Patel-Teja equation of state, which is known to describe well the saturated properties of pure components $\mathrm{CO}_{2}, \mathrm{C}_{2} \mathrm{H}_{5} \mathrm{OH}$ and $\mathrm{H}_{2} \mathrm{O}$, was tried for the correlation of phase equilibria in these binary systems. However, good correlation was not obtained. The most probable reason for this is the assumption of random mixing of molecules in the equation.

To take the local molecular concentration into account, Wilson's model was applied to improve the mixing factor in the Patel-Teja equation. This has remarkably improved correlation for the phase equilibria of the binary systems. It has also been found that the phase behavior of the ternary system can approximately be predicted, but equilibrium concentration estimations are not yet satisfactory.
\end{abstract}

\section{Introduction}

Supercritical fluid extraction has been receiving much attention for its potential for laying the basis of a new process that would be an alternative to energyintensive techniques such as distillation. The technique of supercritical fluid extraction may be applied to the separation of ethanol from the dilute aqueous solutions produced in biochemical processes.

For the dehydration of ethanol, supercritical $\mathrm{CO}_{2}$ has been extensively considered, since it is nonflammable and nontoxic, and allows ambienttemperature operations to be performed. Although a knowledge of the phase equilibria of $\mathrm{CO}_{2}-\mathrm{C}_{2} \mathrm{H}_{5} \mathrm{OH}-$ $\mathrm{H}_{2} \mathrm{O}$ is essential for applications, there has been only a little work $\mathrm{w}^{1,2,6)}$ done on the measurement of these phase equilibria. In the present work, experiments were conducted to measure the equilibria in the above-mentioned ternary system. Our experimental results were then compared with predictions made by a currently adopted estimation method.

\section{Experimental}

The experimental approach for the phase equilibrium measurements in the present work adopted a static type of apparatus in which coexisting phases were continuously cycled. As shown in Figs. $\mathbf{1}$ and $\mathbf{2}$, the apparatus is capable of measuring three-phase equilibria and consists of the following four main parts:

Received July 9, 1985. Correspondence concerning this article should be addressed to S. Saito. K. Saiki is with Chemical Industry Research Center, Kobe Steel Lid., Kobe 651.
- Feed system for each component: $\mathrm{CO}_{2}$ gas cylinder 17 and charging pump 3 for a $\mathrm{C}_{2} \mathrm{H}_{5} \mathrm{OH}-\mathrm{H}_{2} \mathrm{O}$ mixture and liquefied $\mathrm{CO}_{2}$.

-Dual-window equilibrium cell 1 , equipped with magnetic stirrer 11 and connected to recirculation pipes.

- Recycling system for each coexisting phase: magnetic pump 8 and sampling device 6 , connected to a sampling system.

-Sampling system: flash tank 14, magnetic pump 9 and sampling device 7 for the analysis of composition by gas chromatograph 15 .

Except for the feed system, each part of the apparatus is located in a temperature-controlled air bath. Figure 2 shows a sketch of the equilibrium cell. The volume of the equilibrium cell is about $700 \mathrm{~cm}^{3}$.

Each experiment began with the evacuation of the apparatus. $\mathrm{CO}_{2}$ and the mixture $\mathrm{C}_{2} \mathrm{H}_{5} \mathrm{OH}-\mathrm{H}_{2} \mathrm{O}$ of known composition were pumped into the equilibrium cell until a desired pressure was achieved. After long and vigorous stirring with magnetic stirrer 11 , each phase in the equilibrium cell was recirculated. To avoid the condensation of heavier components in the recirculation line for vapor phase, the temperature of air bath 20 was maintained at a slightly higher value than the equilibrium temperature, whereas the temperature in the recirculation line for liquid phase was slightly lower than the equilibrium temperature to avoid the vaporization of $\mathrm{CO}_{2}$. When no further change was detected in pressure and interfacial levels, recirculation was stopped and a small amount of each phase was enclosed in sampler 6 . To vaporize the liquid sample and to prevent condensation of the gas 


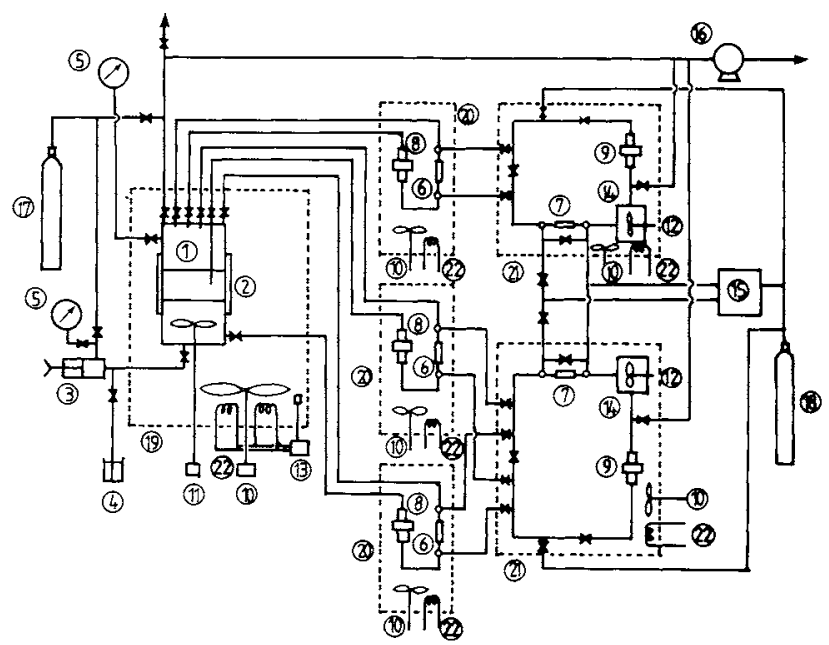

Fig. 1. Schematic diagram of apparatus: 1, equilibrium cell; 2, window; 3, sample-charging pump; 4, liquid sampler; 5, pressure gauge; 6,7 , sampler; 8,9 , magnetic pump; 10 , stirrer; 11,12 , magnetic stirrer; 13 , temperature controller; 14 , flash tank; 15 , gas chromatograph; 16 , vacuum pump; $17, \mathrm{CO}_{2}$ gas cylinder; 18, He gas cylinder; 19-21, air bath; 22, heater.

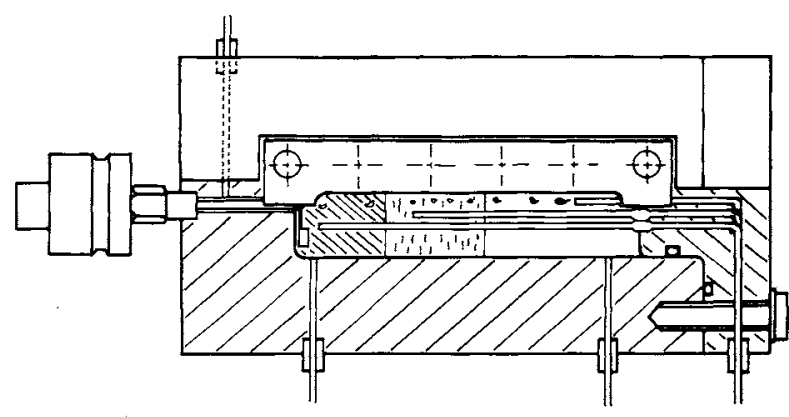

Fig. 2. Equilibrium cell.

sample, the temperatures of air baths 20 were elevated to $393 \mathrm{~K}$, which was the same value as that of sampling systems 21 . After the evacuation of flash tank 14 , the liquid sample was expanded into the tank and recirculated through magnetic pump 9 to homogenize the composition throughout the sampling system. A small quantity of each sample was then transferred to a carrier gas line of gas chromatograph 15 for analysis.

The pressure in the equilibrium cell was measured, using a Bourdon-tube gauge calibrated with a deadweight gauge. The experimental error of pressure measurements was within $10 \mathrm{kPa}$. The temperature was controlled to a degree of error of $0.1 \mathrm{~K}$ and was measured by a quartz thermometer (Hewlett Packard 2804A). Measurements of vapor-liquid equilibria were also conducted for the binary systems $\mathrm{CO}_{2}-$ $\mathrm{C}_{2} \mathrm{H}_{5} \mathrm{OH}$ and $\mathrm{CO}_{2}-\mathrm{H}_{2} \mathrm{O}$.

Liquefied $\mathrm{CO}_{2}$ supplied by Nippon Sanso K.K. $\left(99.9 \%\right.$ ) and $\mathrm{C}_{2} \mathrm{H}_{5} \mathrm{OH}$ supplied by Wako Pure Chem. Ind. Co., Ltd. were used without further purification. $\mathrm{H}_{2} \mathrm{O}$ was ion-exchanged and purified by distillation.

\section{Experimental Results}

\section{$2.1 \mathrm{CO}_{2}-\mathrm{C}_{2} \mathrm{H}_{5} \mathrm{OH}$ and $\mathrm{CO}_{2}-\mathrm{H}_{2} \mathrm{O}$ systems}

Although $\mathrm{Oba}$ et al ${ }^{8)}$ reported vapor-liquid equilibria for the $\mathrm{CO}_{2}-\mathrm{C}_{2} \mathrm{H}_{5} \mathrm{OH}$ system at $333.1 \mathrm{~K}$, only a little work has been done to investigate these equilibria near the critical temperature of $\mathrm{CO}_{2}$. In the present work the phase equilibria were measured for this system at $304.2 \mathrm{~K}$ and $308.2 \mathrm{~K}$. The results are presented in Fig. 3 and Table 1. The equilibrium curve at the critical temperature of $\mathrm{CO}_{2}(304.2 \mathrm{~K})$ shows a very sharp change in the area near the critical point.

Figure 4 shows data of Wiebe and Gaddy ${ }^{15)}$ for the $\mathrm{CO}_{2}-\mathrm{H}_{2} \mathrm{O}$ system at $304.2 \mathrm{~K}$. In the same figure, the experimental results obtained in the present work are also presented. Good agreement can be observed between the two sets of data.

A large difference in phase behavior in the two systems can be seen from Figs. 3 and 4. Namely, for the $\mathrm{CO}_{2}-\mathrm{H}_{2} \mathrm{O}$ system, a three-phase equilibrium appears near the critical pressure of pure $\mathrm{CO}_{2}$, and the region of partially miscible liquids exists above the three-phase line, while these three-phase and twophase regions do not exist for the $\mathrm{CO}_{2}-\mathrm{C}_{2} \mathrm{H}_{5} \mathrm{OH}$ system. This indicates that the affinity of $\mathrm{CO}_{2}$ for $\mathrm{C}_{2} \mathrm{H}_{5} \mathrm{OH}$ is greater than that for $\mathrm{H}_{2} \mathrm{O}$, and that $\mathrm{CO}_{2}$ is a candidate for the solvent in the supercritical fluid extraction of $\mathrm{C}_{2} \mathrm{H}_{5} \mathrm{OH}$ from its aqueous solution.

\section{$2.2 \mathrm{CO}_{2}-\mathrm{C}_{2} \mathrm{H}_{5} \mathrm{OH}-\mathrm{H}_{2} \mathrm{O}$ system}

Figure 5 shows a phase diagram for the system $\mathrm{CO}_{2}-\mathrm{C}_{2} \mathrm{H}_{5} \mathrm{OH}-\mathrm{H}_{2} \mathrm{O}$ at the temperature $304.2 \mathrm{~K}$ and the pressure $6.87 \mathrm{MPa}$, which is slightly below the critical pressure of $\mathrm{CO}_{2}$. The diagram is divided into six different equilibrium regions: the single-vapor phase region $\mathrm{V}$, the single-liquid phase region $\mathrm{L}_{1}$ or $\mathrm{L}_{2}$, the liquid-liquid equilibrium region $\mathrm{L}_{1}-\mathrm{L}_{2}$, the two vapor-liquid equilibrium regions $L_{1}-V$ and $L_{2}-V$, and the three-phase equilibrium region $\mathrm{L}_{1}-\mathrm{L}_{2}-\mathrm{V}$. The vapor-phase region is limited to a very narrow area around pure $\mathrm{CO}_{2}$.

Figure 6 shows the changes in the three-phase equilibrium with pressure at the temperature $304.2 \mathrm{~K}$. The shaded circle plotted in the figure is a measurement reported by Kuenen and Robinson ${ }^{5)}$ for the system $\mathrm{CO}_{2}-\mathrm{H}_{2} \mathrm{O}$ at $7.33 \mathrm{MPa}$. It can be seen from the figure that the composition of the $\mathrm{H}_{2} \mathrm{O}$-rich liquid phase $\mathrm{L}_{1}$ changes considerably with a small change of pressure.

Figure 7 shows liquid-(supercritical)fluid equilibria measured at the pressure $10.1 \mathrm{MPa}$ and the temperature $308.2 \mathrm{~K}$, slightly above the critical temperature of $\mathrm{CO}_{2}$. Liquid-fluid equilibria under conditions close to those in our work have also been reported by Kuk and Montagna. ${ }^{6)}$ Their data are plotted in Fig. 7. The two sets of data in Fig. 7 are very similar.

The experimental results obtained by us are sum- 


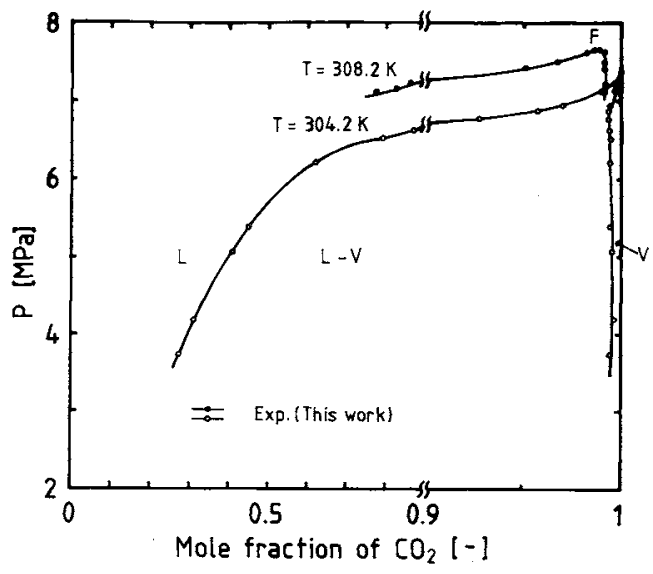

Fig. 3. Vapor-liquid equilibria for $\mathrm{CO}_{2}-\mathrm{C}_{2} \mathrm{H}_{5} \mathrm{OH}$ system.

Table 1. Vapor-liquid equilibria for $\mathrm{CO}_{2}-\mathrm{C}_{2} \mathrm{H}_{5} \mathrm{OH}$ system

\begin{tabular}{|c|c|c|c|c|}
\hline \multirow{3}{*}{$\begin{array}{c}\text { Pressure } \\
\text { [MPa] }\end{array}$} & \multicolumn{4}{|c|}{ Mole fraction [-] } \\
\hline & \multicolumn{2}{|c|}{ Vapor phase } & \multicolumn{2}{|c|}{ Liquid phase } \\
\hline & $\mathrm{CO}_{2}$ & $\mathrm{C}_{2} \mathrm{H}_{5} \mathrm{OH}$ & $\mathrm{CO}_{2}$ & $\mathrm{C}_{2} \mathrm{H}_{5} \mathrm{OH}$ \\
\hline \multicolumn{5}{|c|}{$T=304.2 \mathrm{~K}$} \\
\hline 3.75 & 0.994 & 0.006 & 0.273 & 0.727 \\
\hline 4.19 & 0.996 & 0.004 & 0.313 & 0.687 \\
\hline 5.09 & 0.995 & 0.005 & 0.410 & 0.590 \\
\hline 5.40 & 0.994 & 0.006 & 0.450 & 0.550 \\
\hline 6.22 & 0.994 & 0.006 & 0.620 & 0.380 \\
\hline 6.51 & 0.994 & 0.006 & 0.791 & 0.209 \\
\hline 6.63 & 0.993 & 0.007 & 0.869 & 0.131 \\
\hline 6.77 & 0.993 & 0.007 & 0.927 & 0.073 \\
\hline 6.87 & 0.993 & 0.007 & 0.957 & 0.043 \\
\hline 6.95 & 0.994 & 0.006 & 0.970 & 0.030 \\
\hline 7.13 & 0.996 & 0.004 & 0.989 & 0.011 \\
\hline 7.22 & 0.998 & 0.002 & 0.996 & 0.004 \\
\hline \multicolumn{5}{|c|}{$T=308.2 \mathrm{~K}$} \\
\hline 7.12 & 0.991 & 0.009 & 0.774 & 0.226 \\
\hline 7.16 & 0.991 & 0.009 & 0.826 & 0.174 \\
\hline 7.23 & 0.991 & 0.009 & 0.860 & 0.140 \\
\hline 7.44 & 0.991 & 0.009 & 0.951 & 0.049 \\
\hline 7.52 & 0.991 & 0.009 & 0.967 & 0.033 \\
\hline 7.64 & 0.991 & 0.009 & 0.982 & 0.018 \\
\hline 7.67 & 0.989 & 0.011 & 0.986 & 0.014 \\
\hline
\end{tabular}

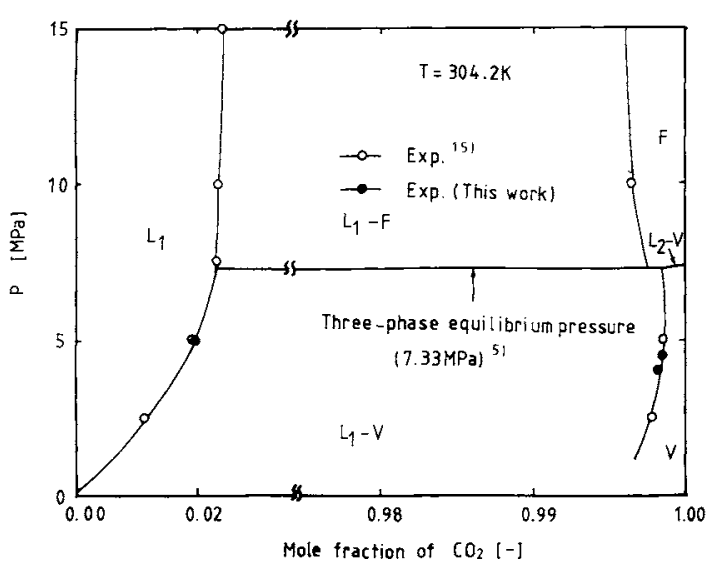

Fig. 4. Phase equilibria for $\mathrm{CO}_{2}-\mathrm{H}_{2} \mathrm{O}$ system.
Table 2. Phase equilibria for $\mathrm{CO}_{2}-\mathrm{C}_{2} \mathrm{H}_{5} \mathrm{OH}-\mathrm{H}_{2} \mathrm{O}$ system

\begin{tabular}{|c|c|c|c|c|}
\hline \multirow{2}{*}{$\begin{array}{c}\text { Pressure } \\
{[\mathrm{MPa}]}\end{array}$} & \multirow[b]{2}{*}{ Component } & \multicolumn{3}{|c|}{ Mole fraction $[-]$} \\
\hline & & Vapor & Liquid $_{1}$ & $\begin{array}{l}\text { Liquid }_{2} \\
\text { (Fluid) }\end{array}$ \\
\hline \multicolumn{5}{|c|}{$T=304.2 \mathrm{~K}$} \\
\hline 6.78 & $\begin{array}{l}\mathrm{CO}_{2} \\
\mathrm{C}_{2} \mathrm{H}_{5} \mathrm{OH} \\
\mathrm{H}_{2} \mathrm{O}\end{array}$ & $\begin{array}{l}0.994 \\
0.005 \\
0.001\end{array}$ & $\begin{array}{l}0.534 \\
0.339 \\
0.127\end{array}$ & $\begin{array}{l}0.862 \\
0.114 \\
0.024\end{array}$ \\
\hline 6.79 & $\begin{array}{l}\mathrm{CO}_{2} \\
\mathrm{C}_{2} \mathrm{H}_{5} \mathrm{OH} \\
\mathrm{H}_{2} \mathrm{O}\end{array}$ & $\begin{array}{l}0.992 \\
0.006 \\
0.002\end{array}$ & $\begin{array}{l}0.425 \\
0.384 \\
0.191\end{array}$ & $\begin{array}{l}- \\
-\end{array}$ \\
\hline 6.79 & $\begin{array}{l}\mathrm{CO}_{2} \\
\mathrm{C}_{2} \mathrm{H}_{5} \mathrm{OH} \\
\mathrm{H}_{2} \mathrm{O}\end{array}$ & $\begin{array}{l}0.993 \\
0.004 \\
0.003\end{array}$ & $\begin{array}{l}0.042 \\
0.152 \\
0.806\end{array}$ & $\begin{array}{l}- \\
- \\
-\end{array}$ \\
\hline 6.87 & $\begin{array}{l}\mathrm{CO}_{2} \\
\mathrm{C}_{2} \mathrm{H}_{5} \mathrm{OH} \\
\mathrm{H}_{2} \mathrm{O}\end{array}$ & $\begin{array}{l}0.994 \\
0.004 \\
0.002\end{array}$ & $\begin{array}{l}0.044 \\
0.152 \\
0.804\end{array}$ & - \\
\hline 6.87 & $\begin{array}{l}\mathrm{CO}_{2} \\
\mathrm{C}_{2} \mathrm{H}_{5} \mathrm{OH} \\
\mathrm{H}_{2} \mathrm{O}\end{array}$ & $\begin{array}{l}0.993 \\
0.004 \\
0.003\end{array}$ & $\begin{array}{l}0.112 \\
0.286 \\
0.602\end{array}$ & $\begin{array}{l}- \\
-\end{array}$ \\
\hline 6.87 & $\begin{array}{l}\mathrm{CO}_{2} \\
\mathrm{C}_{2} \mathrm{H}_{5} \mathrm{OH} \\
\mathrm{H}_{2} \mathrm{O}\end{array}$ & $\begin{array}{l}0.992 \\
0.006 \\
0.002\end{array}$ & $\begin{array}{l}0.277 \\
0.390 \\
0.333\end{array}$ & $\begin{array}{l}0.929 \\
0.056 \\
0.015\end{array}$ \\
\hline 6.87 & $\begin{array}{l}\mathrm{CO}_{2} \\
\mathrm{C}_{2} \mathrm{H}_{5} \mathrm{OH} \\
\mathrm{H}_{2} \mathrm{O}\end{array}$ & - & $\begin{array}{l}0.529 \\
0.342 \\
0.129\end{array}$ & $\begin{array}{l}0.865 \\
0.112 \\
0.023\end{array}$ \\
\hline 6.99 & $\begin{array}{l}\mathrm{CO}_{2} \\
\mathrm{C}_{2} \mathrm{H}_{5} \mathrm{OH} \\
\mathrm{H}_{2} \mathrm{O}\end{array}$ & $\begin{array}{l}0.988 \\
0.007 \\
0.005\end{array}$ & $\begin{array}{l}0.050 \\
0.150 \\
0.800\end{array}$ & $\begin{array}{l}0.959 \\
0.024 \\
0.017\end{array}$ \\
\hline 10.08 & $\begin{array}{l}\quad T=308 . \\
\mathrm{CO}_{2} \\
\mathrm{C}_{2} \mathrm{H}_{5} \mathrm{OH} \\
\mathrm{H}_{2} \mathrm{O}\end{array}$ & $\begin{array}{l}\mathrm{K} \\
- \\
-\end{array}$ & $\begin{array}{l}0.036 \\
0.081 \\
0.883\end{array}$ & $\begin{array}{l}0.972 \\
0.016 \\
0.012\end{array}$ \\
\hline 10.07 & $\begin{array}{l}\mathrm{CO}_{2} \\
\mathrm{C}_{2} \mathrm{H}_{5} \mathrm{OH} \\
\mathrm{H}_{2} \mathrm{O}\end{array}$ & $\begin{array}{l}- \\
- \\
-\end{array}$ & $\begin{array}{l}0.046 \\
0.154 \\
0.799\end{array}$ & $\begin{array}{l}0.961 \\
0.030 \\
0.009\end{array}$ \\
\hline 10.08 & $\begin{array}{l}\mathrm{CO}_{2} \\
\mathrm{C}_{2} \mathrm{H}_{5} \mathrm{OH} \\
\mathrm{H}_{2} \mathrm{O}\end{array}$ & $\begin{array}{l}- \\
- \\
-\end{array}$ & $\begin{array}{l}0.087 \\
0.247 \\
0.666\end{array}$ & $\begin{array}{l}0.942 \\
0.045 \\
0.013\end{array}$ \\
\hline 10.08 & $\begin{array}{l}\mathrm{CO}_{2} \\
\mathrm{C}_{2} \mathrm{H}_{5} \mathrm{OH} \\
\mathrm{H}_{2} \mathrm{O}\end{array}$ & $\begin{array}{l}- \\
- \\
-\end{array}$ & $\begin{array}{l}0.324 \\
0.377 \\
0.299\end{array}$ & $\begin{array}{l}0.891 \\
0.088 \\
0.021\end{array}$ \\
\hline 10.31 & $\begin{array}{l}\mathrm{CO}_{2} \\
\mathrm{C}_{2} \mathrm{H}_{5} \mathrm{OH} \\
\mathrm{H}_{2} \mathrm{O}\end{array}$ & $\begin{array}{l}- \\
-\end{array}$ & $\begin{array}{l}0.430 \\
0.359 \\
0.211\end{array}$ & $\begin{array}{l}0.855 \\
0.114 \\
0.031\end{array}$ \\
\hline
\end{tabular}

marized schematically in the general form of the phase diagrams to show the phase behavior as a function of pressure in Fig. 8 .

Mole fractions of $\mathrm{C}_{2} \mathrm{H}_{5} \mathrm{OH}$ in the supercritical fluid and the liquid phases at $308.2 \mathrm{~K}$ and $10.1 \mathrm{MPa}$ on a $\mathrm{CO}_{2}$-free basis are presented in Fig. 9. To compare supercritical fluid extraction and distillation, a vaporliquid equilibrium curve for the $\mathrm{C}_{2} \mathrm{H}_{5} \mathrm{OH}-\mathrm{H}_{2} \mathrm{O}$ system at atmospheric pressure from the literature ${ }^{3 y}$ is also presented in the same figure. In the region of relatively low concentrations of $\mathrm{C}_{2} \mathrm{H}_{5} \mathrm{OH}$, higher 


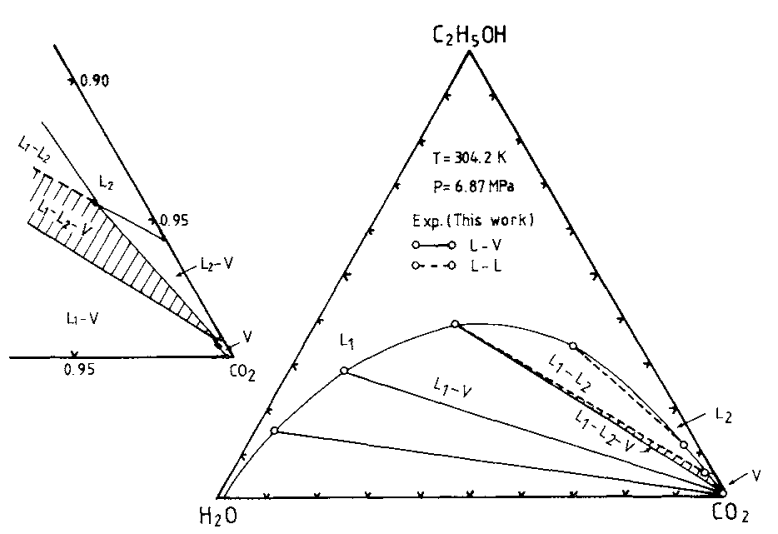

Fig. 5. Phase equilibria for $\mathrm{CO}_{2}-\mathrm{C}_{2} \mathrm{H}_{5} \mathrm{OH}-\mathrm{H}_{2} \mathrm{O}$ system.

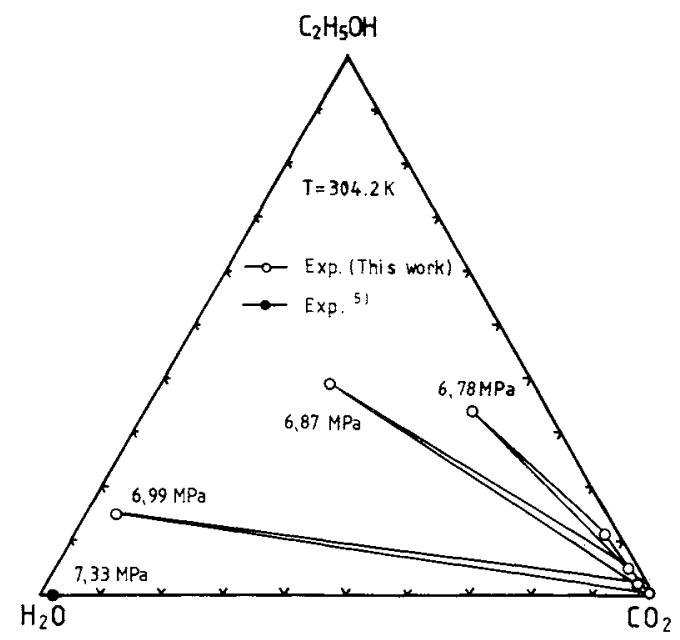

Fig. 6. Three-phase equilibria for $\mathrm{CO}_{2}-\mathrm{C}_{2} \mathrm{H}_{5} \mathrm{OH}-\mathrm{H}_{2} \mathrm{O}$ system.

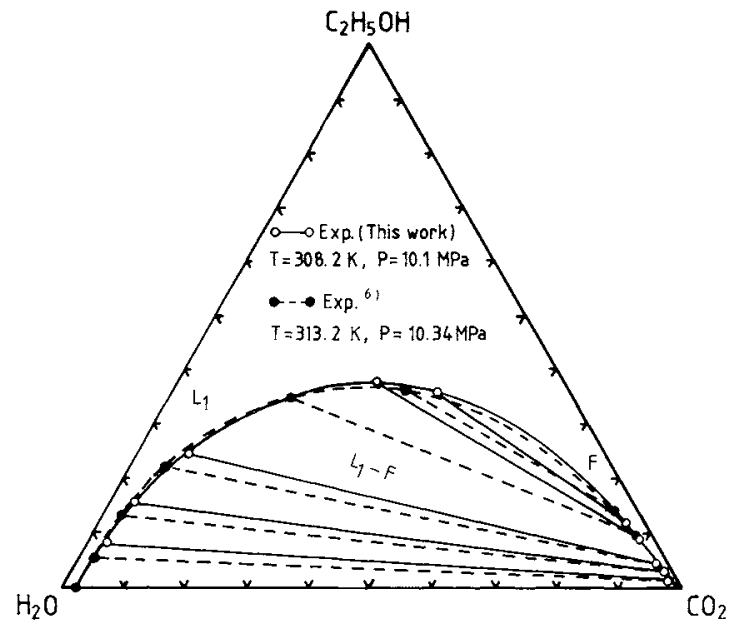

Fig. 7. Liquid-fluid equilibria for $\mathrm{CO}_{2}-\mathrm{C}_{2} \mathrm{H}_{5} \mathrm{OH}-\mathrm{H}_{2} \mathrm{O}$ system.

selectivity of $\mathrm{C}_{2} \mathrm{H}_{5} \mathrm{OH}$ is shown to be achieved in the fluid-liquid equilibria under the supercritical condition of $\mathrm{CO}_{2}$. However, an upper limit of $\mathrm{C}_{2} \mathrm{H}_{5} \mathrm{OH}$ concentration exists around $80 \mathrm{~mol} \% \quad(91 \mathrm{wt} \%)$, which is smaller than the azeotropic concentration of

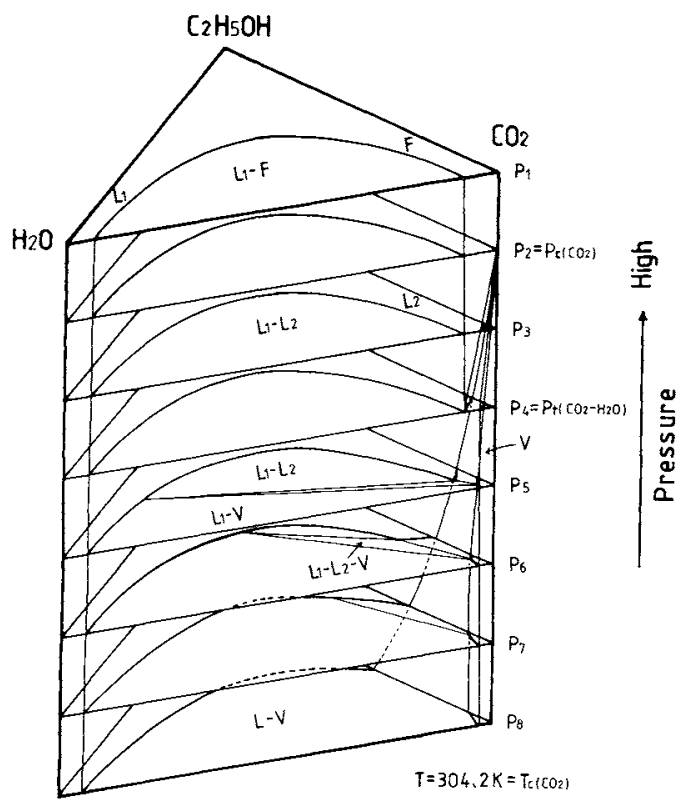

Fig. 8. Phase diagram for $\mathrm{CO}_{2}-\mathrm{C}_{2} \mathrm{H}_{5} \mathrm{OH}-\mathrm{H}_{2} \mathrm{O}$ system.

$89.5 \mathrm{~mol} \%(95.6 \mathrm{wt} \%)$ for atmospheric distillation.

The existence of the upper limit is probably attributable to the relatively strong affinity between $\mathrm{CO}_{2}$ and $\mathrm{C}_{2} \mathrm{H}_{5} \mathrm{OH}$ molecules. This can be deduced from Fig. 10, drawn using the experimental results of ternary liquid-fluid equilibria at $308.2 \mathrm{~K}$ and 10.1 MPa. The solubility of $\mathrm{CO}_{2}$ in the liquid phase and that of $\mathrm{C}_{2} \mathrm{H}_{5} \mathrm{OH}$ in the fluid phase increase exponentially up to the plait point, with an increase in the mole fraction of $\mathrm{C}_{2} \mathrm{H}_{5} \mathrm{OH}$ in the liquid phase. For application of the supercritical fluid extraction of $\mathrm{C}_{2} \mathrm{H}_{5} \mathrm{OH}$, a high degree of $\mathrm{C}_{2} \mathrm{H}_{5} \mathrm{OH}$ solubility in the fluid phase seems to be desirable. However, as shown in Figs. 9 and 10, an increase in solubility leads to a decrease in selectivity. Consequently, there appears an upper limit for $\mathrm{C}_{2} \mathrm{H}_{5} \mathrm{OH}$ in the fluid phase. Although this limitation changes somewhat with temperature and pressure, a large change should not be expected, as is suggested in the report of Baker and Anderson. ${ }^{1)}$ To raise the limitation, it seems necessary to investigate entrainers which suppress the solubility of $\mathrm{CO}_{2}$ in the liquid phase and/or the solubility of $\mathrm{H}_{2} \mathrm{O}$ in the fluid phase.

\section{Estimation of Phase Equilibrium by Means of Equation of State}

\subsection{Equation of state}

A general method for the estimation of phase equilibria can be derived on the basis of an equation of state. Applying this method, the present work attempts to estimate the experimental results. Table 3 presents a list of equations of state which are currently adopted for the estimation of phase equilibria with the results of the estimation of saturated properties for the pure components of $\mathrm{CO}_{2}, \mathrm{C}_{2} \mathrm{H}_{5} \mathrm{OH}$ and 


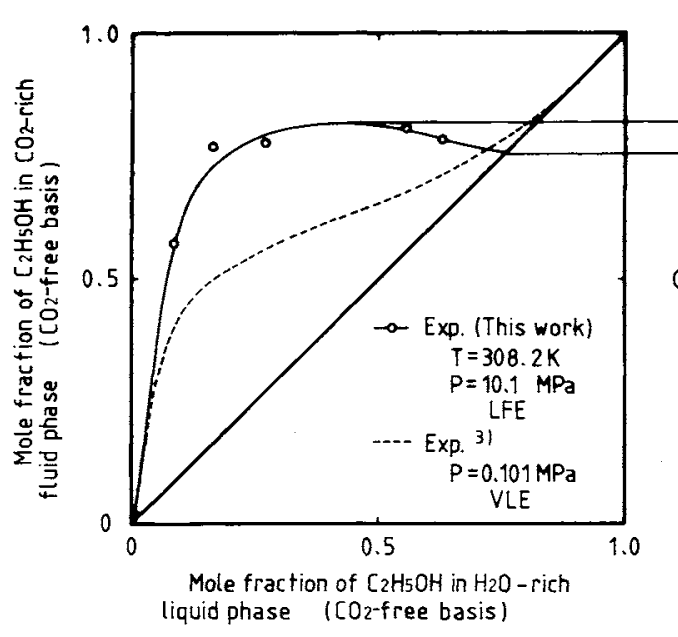

(a)

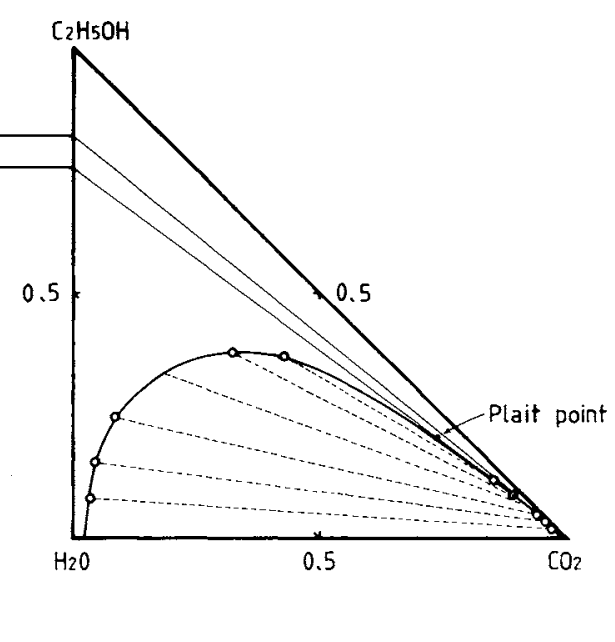

(b)

Fig. 9. $\mathrm{C}_{2} \mathrm{H}_{5} \mathrm{OH}$ concentration profile.

Table 3. Average absolute deviation $[\%]$ in saturated properties

\begin{tabular}{|c|c|c|c|c|c|c|c|c|c|}
\hline \multirow{2}{*}{ Equation } & \multicolumn{3}{|c|}{$\mathrm{CO}_{2}$} & \multicolumn{3}{|c|}{$\mathrm{C}_{2} \mathrm{H}_{5} \mathrm{OH}$} & \multicolumn{3}{|c|}{$\mathrm{H}_{2} \mathrm{O}$} \\
\hline & $P^{s}$ & $\rho_{L}^{s}$ & $\rho_{V}^{s * *}$ & $P^{s}$ & $\rho_{L}^{s}$ & $\rho_{V}^{s}$ & $P^{s}$ & $\rho_{L}^{s}$ & $\rho_{V}^{s}$ \\
\hline S-R-K* & 0.631 & 13.257 & 1.324 & 2.587 & 20.599 & 6.404 & 6.362 & 28.455 & 7.847 \\
\hline P-R & 0.282 & 4.753 & 1.768 & 0.859 & 10.771 & 3.034 & 3.698 & 19.215 & 5.775 \\
\hline $\mathrm{H}-\mathrm{K}$ & 0.742 & 5.189 & 1.730 & 5.273 & 8.473 & 6.279 & 5.529 & 15.315 & 7.472 \\
\hline S-W & 0.635 & 5.550 & 1.085 & 1.812 & 7.831 & 2.110 & 4.967 & 18.875 & 6.710 \\
\hline P-T & 0.501 & 1.849 & 1.540 & 3.420 & 2.364 & 5.648 & 1.390 & 1.767 & 2.205 \\
\hline Fuller & 0.334 & 1.779 & 2.499 & 1.575 & 4.027 & 3.502 & 4.819 & 3.187 & 5.927 \\
\hline BWR-S & 2.060 & 2.151 & 2.492 & 17.610 & 7.905 & 19.348 & 12.292 & 6.827 & 11.350 \\
\hline \multirow[t]{2}{*}{ BWR-SN } & 2.738 & 2.090 & 2.700 & 2.398 & 7.978 & 3.080 & 13.534 & 6.621 & 12.743 \\
\hline & \multicolumn{3}{|c|}{$\left(\mathrm{T}_{r}=0.712-1.0\right)$} & \multicolumn{3}{|c|}{$\left(T_{r}=0.529-1.0\right)$} & \multicolumn{3}{|c|}{$\left(T_{r}=0.422-1.0\right)$} \\
\hline
\end{tabular}

* S-R-K, Soave-Redlich-Kwong equation; ${ }^{12)}$ P-R, Peng-Robinson equation; ${ }^{10)}$ H-K, Harmens-Knapp equation, ${ }^{4 !} \mathrm{S}-\mathrm{W}$, SchmidtWenzel equation; ${ }^{11}$ P-T, Patel-Teja equation; ${ }^{9,14}$ BWR-S, BWR-Starling equation (11 constants): ${ }^{13)}$ BWR-SN, Modified BWR equation (15 constants). ${ }^{7}$

** $P^{s}$, saturated vapor pressure; $\rho_{L}^{s}$, molar density of saturated liquid phase; $\rho_{V}^{s}$, molar density of saturated vapor phase.

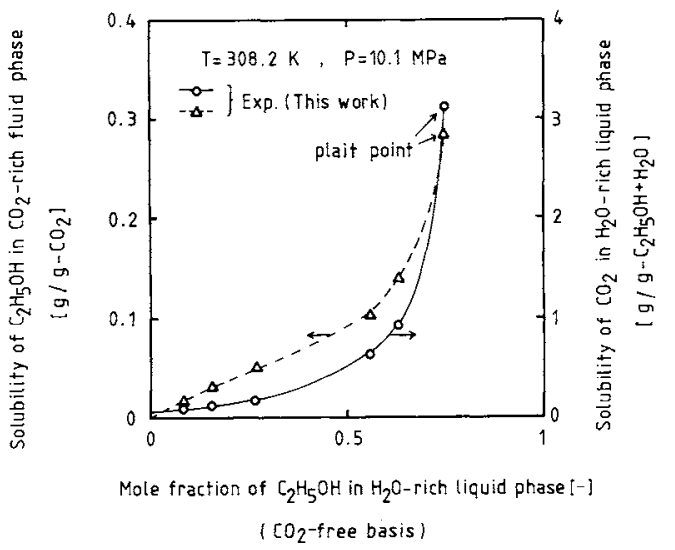

Fig. 10. Solubilities of $\mathrm{C}_{2} \mathrm{H}_{5} \mathrm{OH}$ in fluid phase and of $\mathrm{CO}_{2}$ in liquid phase.

$\mathrm{H}_{2} \mathrm{O}$. Judging from the deviations, the equation of Patel and Teja ${ }^{9,14)}$ tends to produce better results than the others. Therefore, the Patel-Teja equation has been used in this work.

Their equation of state is expressed as follows ${ }^{9,14)}$ :

$$
\begin{aligned}
P= & \frac{R T}{v-b}-\frac{a}{v(v+b)+c(v-b)} \\
& a=\Omega_{a}\left(R^{2} T_{c}^{2} / P_{c}\right) \alpha\left(T_{r}\right) \\
& b=\Omega_{b} R T_{c} / P_{c} \\
& c=\Omega_{c} R T_{c} / P_{c} \\
& \Omega_{a}=3 \zeta_{c}^{2}+3\left(1-2 \zeta_{c}\right) \Omega_{b}+\Omega_{b}^{2}+1-3 \zeta_{c} \\
& \Omega_{b}^{3}+\left(2-3 \zeta_{c}\right) \Omega_{b}^{2}+3 \zeta_{c}^{2} \Omega_{b}-\zeta_{c}^{3}=0 \\
& \Omega_{c}=1-3 \zeta_{c} \\
& \alpha\left(T_{r}\right)=\left\{1+F\left(1-T_{r}^{1 / 2}\right)\right\}^{2} \\
& T_{r}=T / T_{c}
\end{aligned}
$$

where the parameter $a$ is a function of temperature, $b$ and $c$ are constants, $F$ and $\zeta_{c}$ : substance-dependent 
parameters, $P$ : pressure, $P_{c}$ : the critical pressure, $R$ : the gas constant, $T$ : absolute temperature, $T_{c}$ : the critical temperature and $v$ : molar volume. The parameters $a, b$ and $c$ in Eq. (1) are determined from $P_{c}$, $T_{c}, F$ and $\zeta_{c}$. Table 4 presents the parameter values of $F$ and $\zeta_{c}$ for $\mathrm{CO}_{2}, \mathrm{C}_{2} \mathrm{H}_{5} \mathrm{OH}$ and $\mathrm{H}_{2} \mathrm{O}$.

\subsection{Mixing rule}

In applying an equation of state for a mixture system, one of the important factors is the choice of mixing rule. Patel and Teja ${ }^{914}$ used the following conventional mixing rule based on a one-fluid model, which assumes a random distribution of molecules.

$$
\begin{aligned}
a_{m} & =\sum_{i} \sum_{j} x_{i} x_{j} a_{i j} \\
a_{i j} & =\left(1-k_{i j}\right)\left(a_{i} a_{j}\right)^{1 / 2} \\
b_{m} & =\sum_{i} x_{i} b_{i} \\
c_{m} & =\sum_{i} x_{i} c_{i}
\end{aligned}
$$

where $x_{i}$ is the mole fraction of component $i$, and $k_{i j}$ is an adjustable parameter for the $i-j$ mixture. For the systems of $\mathrm{CO}_{2}-\mathrm{C}_{2} \mathrm{H}_{5} \mathrm{OH}, \mathrm{CO}_{2}-\mathrm{H}_{2} \mathrm{O}$ and $\mathrm{C}_{2} \mathrm{H}_{5} \mathrm{OH}-$ $\mathrm{H}_{2} \mathrm{O}$, phase equilibria were calculated with Eqs. (1) through (13), and compared with the measurements in Figs. 11 through 13. In the calculations, the optimum values of $k_{i j}$ were determined by fitting the data. Although the results calculated with these $k_{i j}$ values fit well the experimental results in Fig. 11, the calculated results in Figs. 12 and 13 are seen not to be satisfactory.

There may be a number of reasons for this. One may be the inadequacy of the mixing rule, which is based on the assumption of a random molecular distribution. This mixing rule is considered to be essentially applicable to non-polar components. Therefore, for systems containing polar components, especially $\mathrm{H}_{2} \mathrm{O}$ and $\mathrm{C}_{2} \mathrm{H}_{5} \mathrm{OH}$ whose molecules are associated, it seems more suitable to use a mixing rule taking the effect of local molecular concentration into account. It is believed that Wilson's model, ${ }^{16)}$ which considers this effect, is widely applicable to vaporliquid equilibria. The present work attempts to apply this model.

According to this model, ${ }^{16)}$ the local mole fraction of molecule $j$ around $i, x_{j i}$, is expressed by the following equations:

$$
\begin{gathered}
x_{j i}=x_{j} \eta_{j i} /\left(\sum_{k} x_{k} \eta_{k i}\right) \\
\eta_{j i}=\exp \left\{-\left(\lambda_{j i}-\lambda_{i i}\right) / R T\right\}
\end{gathered}
$$

where $\lambda_{j i}$ is the interaction energy between $j$ and $i$ molecules and is assumed to be equal to $\lambda_{i j}$. The following equation, which is based on the concept of local concentration, can be assumed for the mixing
Table 4. Values of parameters $F$ and $\zeta_{c}$

\begin{tabular}{ccc}
\hline Component & $F$ & $\zeta_{c}$ \\
\hline $\mathrm{CO}_{2}$ & 0.7077 & 0.309 \\
$\mathrm{C}_{2} \mathrm{H}_{5} \mathrm{OH}$ & 1.2304 & 0.300 \\
$\mathrm{H}_{2} \mathrm{O}$ & 0.6898 & 0.269 \\
\hline
\end{tabular}

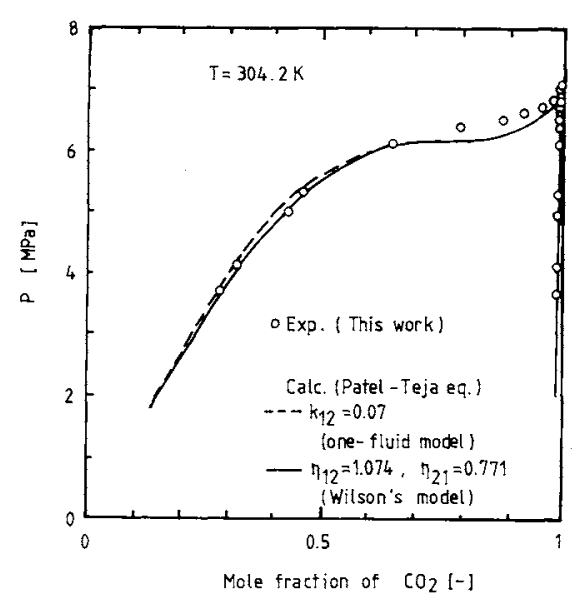

Fig. 11. Comparison of calculated and experimental vaporliquid equilibria for $\mathrm{CO}_{2}-\mathrm{C}_{2} \mathrm{H}_{5} \mathrm{OH}$ system.

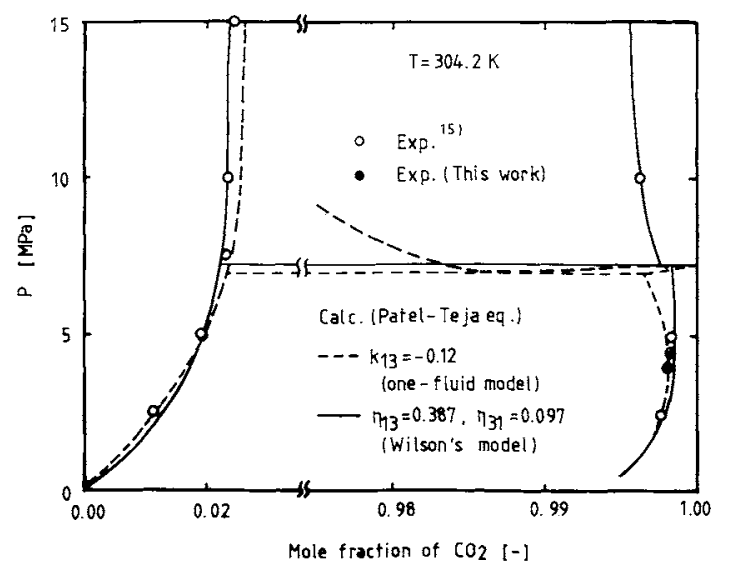

Fig. 12. Comparison of calculated and experimental phase equilibria for $\mathrm{CO}_{2}-\mathrm{H}_{2} \mathrm{O}$ system.

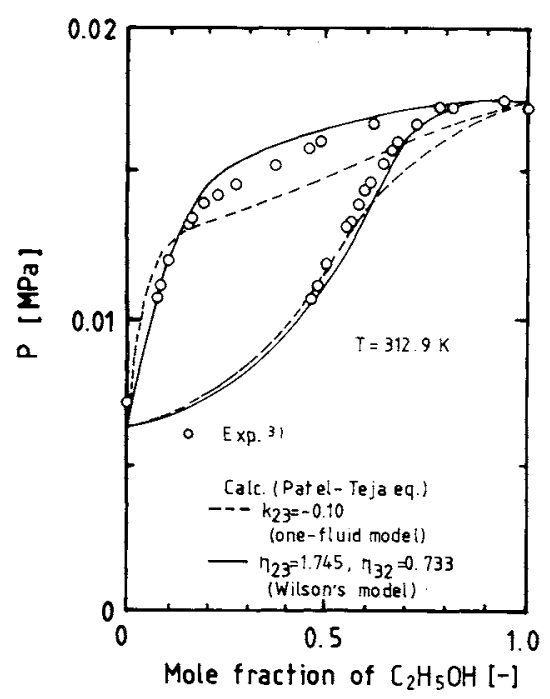

Fig. 13. Comparison of calculated and experimental vaporliquid equilibria for $\mathrm{C}_{2} \mathrm{H}_{5} \mathrm{OH}-\mathrm{H}_{2} \mathrm{O}$ system. 
rule:

$$
a_{m}=\sum_{i} \sum_{j} x_{i} x_{j i} a_{j i}
$$

where $a_{j i}$ is a binary interaction parameter assumed to be approximated by

$$
a_{j i}=\left(a_{j} a_{i}\right)^{1 / 2}
$$

For the parameters of $b_{m}$ and $c_{m}$, Eqs. (12) and (13) were applied in the present work. Thus the parameters in Eq. (1) are determined using Eqs. (12) through (17) for mixing rules. The parameter $\eta_{j i}$ is treated as an adjustable parameter.* The fugacity equation used for the equilibrium calculation is shown in Appendix.

\subsection{Comparison of calculated and experimental results}

Calculations were carried out with Wilson's model for the binary systems $\mathrm{CO}_{2}-\mathrm{C}_{2} \mathrm{H}_{5} \mathrm{OH}, \mathrm{CO}_{2}-\mathrm{H}_{2} \mathrm{O}$ and $\mathrm{C}_{2} \mathrm{H}_{5} \mathrm{OH}-\mathrm{H}_{2} \mathrm{O}$. The parameter $\eta_{i j}$ values were determined so as to minimize estimation error and are listed in Table 5. The calculated results are presented in Figs. 11 through 13. It can be seen that the introduction of Wilson's model results in a better correlation than is obtained with the one-fluid model.

Using the parameter values determined, phase equilibria for the $\mathrm{CO}_{2}-\mathrm{C}_{2} \mathrm{H}_{5} \mathrm{OH}-\mathrm{H}_{2} \mathrm{O}$ system were estimated. The calculated results are shown in Figs. 14 through 16. From Figs. 14 and 15, which represent the two-phase equilibria, it can be found that the slopes of the calculated tie lines are nearly consistent with the experimental ones, although the estimated values of concentrations are not yet satisfactory. As shown in Fig. 16, the agreement between the theoretically predicted and experimental data is not fully quantitative yet for the three-phase equilibria, which are very sensitive even to a small change of pressure.

Two reasons may be responsible for this discrepancy. One may be the inadequacy of the Patel-Teja equation of state, particularly to describe the $P-V-T$ behavior near the critical point of $\mathrm{CO}_{2}$. Another may be the mixing rules applied here for the system containing highly associated components. As is well known, $\mathrm{H}_{2} \mathrm{O}$ and $\mathrm{C}_{2} \mathrm{H}_{5} \mathrm{OH}$ molecules are associated with each other and make cross-associated molecules. Addition of $\mathrm{CO}_{2}$ in aqueous ethanol solution may have some influence on the association equilibria and consequently on the phase equilibria of the system. Among the interactions between $\mathrm{CO}_{2}$ and various associated molecules, the interaction between $\mathrm{CO}_{2}$ and self-associated $\mathrm{H}_{2} \mathrm{O}$ or $\mathrm{C}_{2} \mathrm{H}_{5} \mathrm{OH}$ molecules could be taken into account in the mixing rules applied in this work by treating $\eta_{j i}$ as an adjustable parameter. However, the interaction between $\mathrm{CO}_{2}$ and cross-associated $\mathrm{H}_{2} \mathrm{O}$ and $\mathrm{C}_{2} \mathrm{H}_{5} \mathrm{OH}$ molecules

\footnotetext{
* In the narrow temperature range in our experiments, $\eta_{j i}$ is regarded as a constant which is independent of temperature.
}

Table 5. Values of binary parameters $\eta_{i j}$

\begin{tabular}{lcccc}
\hline & $j$ & 1 & 2 & 3 \\
\cline { 2 - 4 }$i$ & $\left(\mathrm{CO}_{2}\right)$ & $\left(\mathrm{C}_{2} \mathrm{H}_{5} \mathrm{OH}\right)$ & $\left(\mathrm{H}_{2}\right)$ \\
\hline $1\left(\mathrm{CO}_{2}\right)$ & 1.000 & 1.074 & 0.387 \\
$2\left(\mathrm{C}_{2} \mathrm{H}_{5} \mathrm{OH}\right)$ & 0.771 & 1.000 & 1.745 \\
$3\left(\mathrm{H}_{2} \mathrm{O}\right)$ & 0.097 & 0.733 & 1.000 \\
\hline
\end{tabular}

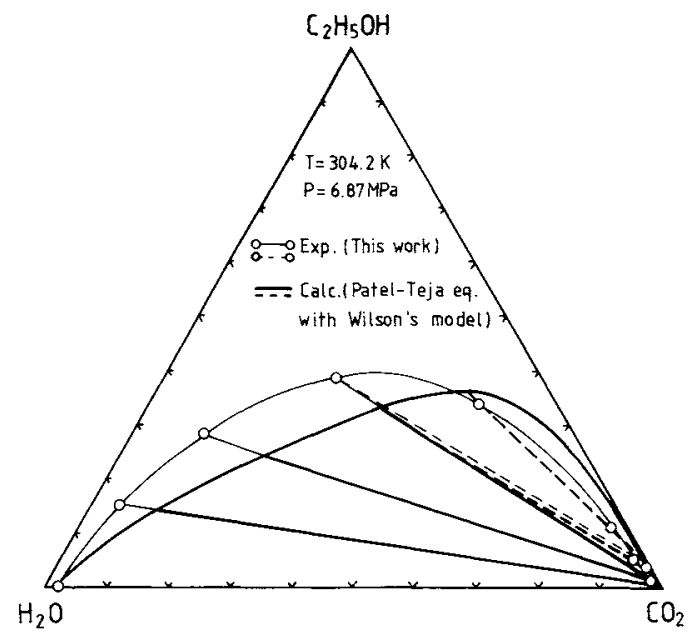

Fig. 14. Comparison of estimated and experimental phase equilibria for $\mathrm{CO}_{2}-\mathrm{C}_{2} \mathrm{H}_{5} \mathrm{OH}-\mathrm{H}_{2} \mathrm{O}$ system.

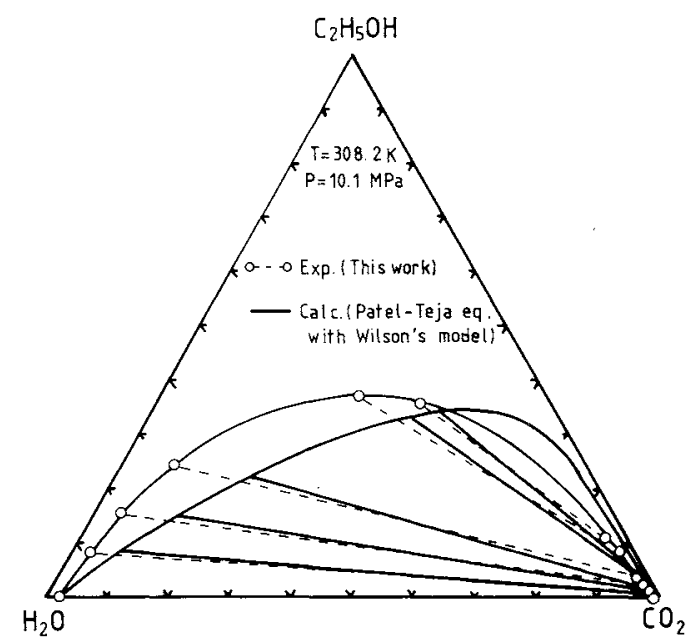

Fig. 15. Comparison of estimated and experimental liquidfluid equilibria for $\mathrm{CO}_{2}-\mathrm{C}_{2} \mathrm{H}_{5} \mathrm{OH}-\mathrm{H}_{2} \mathrm{O}$ system.

could not be considered. For more accurate estimations of the phase equilibria, it may be necessary to develop mixing rules which take the latter interaction into consideration.

\section{Conclusion}

Phase equilibrium data were collected for the ternary system $\mathrm{CO}_{2}-\mathrm{C}_{2} \mathrm{H}_{5} \mathrm{OH}-\mathrm{H}_{2} \mathrm{O}$ and the binary systems $\mathrm{CO}_{2}-\mathrm{C}_{2} \mathrm{H}_{5} \mathrm{OH}$ and $\mathrm{CO}_{2}-\mathrm{H}_{2} \mathrm{O}$. From the data for the ternary system it was found that a high selectivity of $\mathrm{C}_{2} \mathrm{H}_{5} \mathrm{OH}$ can be expected in supercritical fluid extraction with $\mathrm{CO}_{2}$ in the range of low con- 


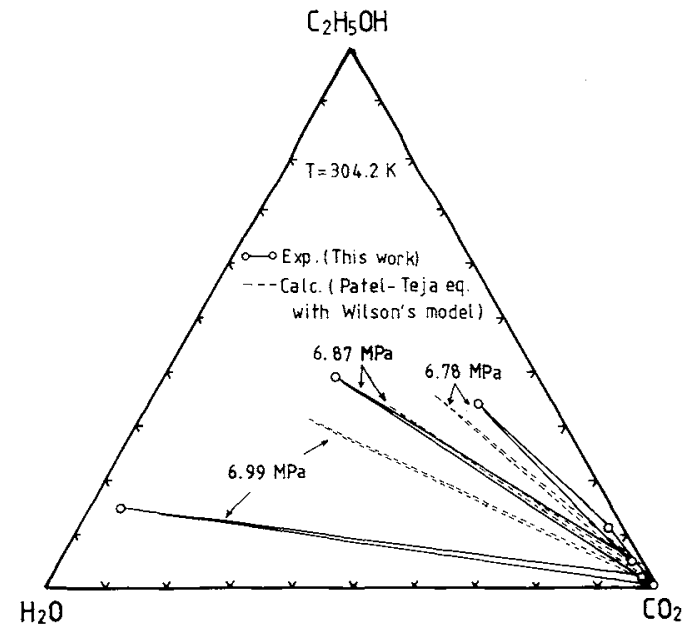

Fig. 16. Comparison of estimated and experimental threephase equilibria for $\mathrm{CO}_{2}-\mathrm{C}_{2} \mathrm{H}_{5} \mathrm{OH}-\mathrm{H}_{2} \mathrm{O}$ system.

centrations of $\mathrm{C}_{2} \mathrm{H}_{5} \mathrm{OH}$, whereas the complete dehydration of $\mathrm{C}_{2} \mathrm{H}_{5} \mathrm{OH}$ was not possible due to the existence of an upper limit of $\mathrm{C}_{2} \mathrm{H}_{5} \mathrm{OH}$ concentration.

The experimental results for the phase equilibria were compared with predictions derived from the Patel-Teja equation of state, accepting their assumption of a random molecular distribution for a mixing rule. However, good estimations were not obtained.

To take into account the effect of local molecular concentration, Wilson's equation was applied to a mixing rule in the Patel-Teja equation. Good correlations were obtained for the phase equilibria of the binary systems. It was also found that the phase behavior of the ternary system can be accurately predicted for a combination of the Patel-Teja equation of state and Wilson's equation, though the concentration estimations are not yet satisfactory. To estimate the concentrations more accurately, equations of state which successfully describe the $P-V-T$ behavior near the critical point of $\mathrm{CO}_{2}$ and mixing rules which take the interaction between $\mathrm{CO}_{2}$ and cross-associated $\mathrm{H}_{2} \mathrm{O}$ and $\mathrm{C}_{2} \mathrm{H}_{5} \mathrm{OH}$, molecules into account may be necessary.

\section{Appendix. Fugacity Expression}

The fugacity of component $i, f_{i}$, is obtained from Eqs. (1) and (12) through (17).

$$
\begin{aligned}
R T \ln \frac{f_{i}}{x_{i} P}= & R T \ln \frac{v}{v-b_{m}}+\frac{b_{i} R T}{v-b_{m}}-R T \ln z \\
& -\left[\frac{1}{\delta} \frac{1}{n}\left(\frac{\partial n^{2} a_{m}}{\partial n_{i}}\right)-\frac{a_{m}}{\delta^{2}}\left\{\left(\frac{\partial n \alpha}{\partial n_{i}}\right)-\left(\frac{\partial n \beta}{\partial n_{i}}\right)\right\}\right] \ln \frac{v-\alpha}{v-\beta} \\
& -\frac{a_{m}}{\delta}\left\{\frac{1}{v-\alpha}\left(\frac{\partial n \alpha}{\partial n_{i}}\right)-\frac{1}{v-\beta}\left(\frac{\partial n \beta}{\partial n_{i}}\right)\right\}
\end{aligned}
$$

where

$z=P v / R T$

$\alpha=-\left(b_{m}+c_{m}-\delta\right) / 2$

$$
\begin{aligned}
& \beta=-\left(b_{m}+c_{m}+\delta\right) / 2 \\
& \delta=\left\{\left(b_{m}+c_{m}\right)^{2}+4 b_{m} c_{m}\right\}^{1 / 2} \\
& \left(\frac{\partial n \alpha}{\partial n_{i}}\right)=-\frac{1}{2}\left\{b_{i}+c_{i}-\left(\frac{\partial n \delta}{\partial n_{i}}\right)\right\} \\
& \left(\frac{\partial n \beta}{\partial n_{i}}\right)=-\frac{1}{2}\left\{b_{i}+c_{i}+\left(\frac{\partial n \delta}{\partial n_{i}}\right)\right\} \\
& \left(\frac{\partial n \delta}{\partial n_{i}}\right)=\frac{1}{2 \delta}\left\{\left(b_{m}+c_{m}\right)\left(b_{i}+c_{i}\right)+2 b_{m} c_{i}+2 b_{i} c_{m}\right\} \\
& \frac{1}{n}\left(\frac{\partial n^{2} a_{m}}{\partial n_{i}}\right)=a^{i}+\sum_{j} x_{j}-\eta_{i j} a_{i j}+\left(\sum_{k} x_{k} \eta_{k j}-\eta_{i j}\right) a^{j} \\
& \sum_{k} x_{k} \eta_{k j} \\
& a^{i}=\sum_{k} x_{k i} a_{k i}=\frac{\sum_{k} x_{k} \eta_{k i} a_{k i}}{\sum_{k} x_{k} \eta_{k i}}
\end{aligned}
$$

$$
\begin{aligned}
& \text { Nomenclature } \\
& a \quad=\text { model parameter defined by Eq. (2) } \quad\left[\mathrm{J} / \mathrm{cm}^{3}\right] \\
& b \quad=\text { model parameter defined by Eq. (3) }\left[\mathrm{cm}^{3}\right] \\
& c \quad=\text { model parameter defined by Eq. (4) } \quad\left[\mathrm{cm}^{3}\right] \\
& F \quad=\text { model parameter in Eq. (8) [-] } \\
& f \quad=\text { fugacity } \quad \text { [MPa] } \\
& k_{i j} \quad=\text { binary parameter in Eq. (11) } \quad[-] \\
& n=\text { mole number [mol] } \\
& P \quad=\text { pressure } \quad[\mathrm{MPa}] \\
& R \quad=\text { gas constant } \quad[\mathbf{J} / \mathrm{K} \cdot \mathrm{mol}] \\
& T \quad=\text { absolute temperature } \quad[\mathrm{K}] \\
& \text { v } \quad=\text { molar volume } \quad\left[\mathrm{cm}^{3} / \mathrm{mol}\right] \\
& x \quad=\text { mole fraction } \quad[-] \\
& z \quad=\text { compressibility factor } \quad[-] \\
& \zeta_{c}=\text { parameter in the Patel-Teja equation of state } \\
& \eta_{i j} \quad=\text { binary parameter for the } i-j \text { mixture } \\
& \lambda_{i j} \quad=\text { interaction energy between } i \text { and } j \text { molecules } \quad[\mathrm{J}] \\
& \rho \quad=\text { molar density } \quad\left[\mathrm{mol} / \mathrm{cm}^{3}\right]
\end{aligned}
$$

〈Subscripts〉

$$
\begin{array}{ll}
c & =\text { critical properties } \\
i, j, k & =\text { properties of components } i, j \text { and } k \\
m & =\text { properties of mixture } \\
1 & =\text { properties of } \mathrm{CO}_{2} \\
2 & =\text { properties of } \mathrm{C}_{2} \mathrm{H}_{5} \mathrm{OH} \\
3 & =\text { properties of } \mathrm{H}_{2} \mathrm{O}
\end{array}
$$

\section{Literature Cited}

1) Baker, L. C. W. and T. F. Anderson: J. Am. Chem. Eng., 79, 2071 (1957).

2) De Filippi, R. P. and J. M. Moses: Biotechnology and Bioengineering Symp., 12, 205 (1982).

3) Gmehling, J. and U. Onken: "Vapor-Liquid Equilibrium Data Collection," Chemistry Data Series Vol. 1, Part 2a, DECHEMA (1977).

4) Harmens, A. and H. Knapp: Ind. Eng. Chem. Fundam., 19, $291(1980)$.

5) Kuenen, J. P. and W. G. Robinson: Phil. Mag., 48, 180 (1899).

6) Kuk, M. S. and J. C. Montagna: "Chemical Engineering at Supercritical Fluid Conditions," Chapter 4, p. 101, Ann Arbor Science Publishers, Ann Arbor, Michigan (1983). 
7) Nishiumi, H. and S. Saito: J. Chem. Eng. Japan, 8, 356 (1975).

8) Oba, S., J. Suzuki, K. Nagahama and M. Hirata: The 18th Autumn Meeting of the Soc. of Chem. Engrs., Japan, Fukuoka, Oct. (1981).

9) Patel, N. C. and A. S. Teja: Chem. Eng. Sci, 37, 463 (1982).

10) Peng, D.-Y. and D. B. Robinson: Ind. Eng. Chem. Fundam., 15, 59 (1976).

11) Schmidt, G. and H. Wenzel: Chem. Eng. Sci., 35, 1503 (1980).
12) Soave, G.: Chem. Eng. Sci., 37, 719 (1972).

13) Starling, K. E. and M. S. Han: Hydrocarbon Processing, 51, $129(1972)$.

14) Teja, A. S. and N. C. Patel: Chem. Eng. Commun., 13, 39 (1981).

15) Wiebe, R. and V. L. Gaddy: J. Am. Chem. Soc., 61, 315 (1939); ibid., 62, 815 (1940); ibid., 63, 475 (1941).

16) Wilson, G. M.: J. Am. Chem. Soc., 86, 127 (1964).

\title{
GAS HOLDUP AND PRESSURE DROP IN THREE-PHASE VERTICAL FLOWS OF GAS-LIQUID-FINE SOLID PARTICLES SYSTEM
}

\author{
YASUO HATATE, HiROSHI NOMURA, TAKANORI FUJITA, \\ SHUICHI TAJIRI, NOBUYUKI HIDAKA AND ATSUSHI IKARI \\ Department of Chemical Engineering, Faculty of Engineering, \\ Kagoshima University, Kagoshima 890
}

Key Words: Multiphase Flow, Gas Holdup, Pressure Drop, Vertical Upflow, Vertical Downflow, Slurry

To obtain information on the hydrodynamics of gas-liquid-fine solid particles flow systems, gas holdup and pressure drop in vertical upflow and downflow tubes were measured at comparatively high fluid velocities.

The following experimental results were obtained.

1) Within the range of experimental conditions, gas holdups in vertical upflow tubes are independent of tube diameter, average size and concentration of solid particles.

2) Frictional pressure drops in vertical upflow tubes are independent of the average size of solid particles, but increase with the concentration of solid particles.

3) Gas holdup in vertical downflow tubes, except at low gas and high slurry velocities, are independent of tube diameter, average size and concentration of solid particles.

4) Frictional pressure drops in vertical downflow tubes are independent of the average size of solid particles, but increase with the concentration of solid particles.

\section{Introduction}

Numerous studies have been conducted on the hydrodynamics of gas-liquid-solid flow, both in bubble columns with suspended solid particles and in three-phase fluidized beds. In these cases, comparatively low fluid vertical upflow velocities are examined. However, in preheater and transportation pipe lines for the coal liquefaction process comparatively high fluid velocities exist in a gas-liquid-solid system. Little information is available on such systems due to the complex properties of the flow and the difficulty in obtaining experimental results. ${ }^{9)}$ For the coal liquefaction process in particular a better understanding of the three-phase hydrodynamics could lead to

Received July 29, 1985. Correspondence concerning this article should be addressed to Y. Hatate. H. Nomura is now at Tokuyama Soda Co., Ltd., Tokuyama 745. T. Fujita is now at Daikin Co., Ltd., Osaka 530 improved predictions of the coal dissolution rate. ${ }^{2)}$

In the present work, measurements of gas holdup and pressure drop in vertical upflow and downflow tubes were carried out at comparatively high fluid velocities to obtain information on the hydrodynamics of gas-liquid-fine solid particle flow systems over a wide range of operating conditions.

\section{Experimental}

Air, city water and fine glass spheres were used as the gas, liquid and solid, respectively. Three cuts of glass particles were used, as listed in Table 1. The finest cut (A) had a mean particle size of just under $30 \mu \mathrm{m}$, the medium cut (B) was $63 \mu \mathrm{m}$ and the large cut (C) was just under $100 \mu \mathrm{m}$. A schematic diagram of the experimental apparatus is shown in Fig. 1. Air from a compressor flows through an air filter and an air/oil separator to eliminate impurities in 